\title{
KARAKTERISTIK JELLY DRINK SINBIOTIK DARI SUSU KEDELAI DAN EKSTRAK BUAH NAGA MERAH (HYLOCEREUS POLYRHIZUS)
}

\author{
Sri Winarti ${ }^{1) *}$, Ulya Sarofa ${ }^{1)}$ dan Koyi Fatkul Rodiyah ${ }^{2}$ \\ ${ }^{1)}$ Staf Pengajar Prodi Teknologi Pangan, Fakultas Teknik UPN "Veteran" Jawa Timur \\ ${ }^{2)}$ Mahasiswa Prodi Teknologi Pangan Fak. Teknik, UPN "Veteran” Jawa Timur \\ Jl. Raya Rungkut Madya Gunung Anyar Surabaya \\ Penulis korespondensi: winarti.sriwing@gmail.com
}

\begin{abstract}
Jelly drink is a gel-based beverage product, which can be made from hydrocolloid compounds by addition of sugars, acids, and or without other food additives, sinbiotics are a combination of probiotics and prebiotics. The purpose of this study was to determine the effect concentration of carrageenan and fermentation timt on the quality of jelly drink sinbiotik soy milk and red dragon fruit extract. The method used in this research is Completely Randomized Design with two factors. The first factor was the concentration of carrageenan $(0.4 \%, 0.6 \%, 0.8 \%)$ and the second factor of fermentation time (18 hours, 20 hours, 22 hours and 24 hours). To know the difference between treatments used Duncan Multiple Range Test (DMRT 5\%). The results showed that the best treatment was the addition of carrageenan $0,8 \%$ and the fermentation time of 24 hours which resulted jelly drink sinbiotik with $\mathrm{pH}$ value 3,7 , total acid $1,02 \%$, total lactic acid bacteria (BAL) 11,13 log cfu/ml, total sugar $7.92 \%, 1.89 \%$ dissolved protein, total anthocyanin $0.645 \%$ and gel strength $3.27 \mathrm{~N}$.
\end{abstract}

Keywords: Jelly drink, sinbiotik, karagenan, dragon fruit, fermentations time.

\section{PENDAHULUAN}

Kesehatan merupakan hal yang sangat penting bagi semua manusia karena tanpa kesehatan yang baik, maka setiap manusia akan sulit dalam melaksanakan aktivitasnya sehari-hari. Upaya untuk meningkatkan kesehatan dapat dilakukan dengan mengkonsumsi minuman fungsional dalam bentuk jelly drink sinbiotik. Penelitian terdahulu yaitu pembuatan jelly drink probiotik. Jelly drink probiotik merupakan minuman fungsional yang berbentuk gel dan mengandung sejumlah bakteri hidup yang bermanfaat dan menjaga keseimbangan mikroflora alami di dalam saluran pencernaan manusia (Prangdimurti, 2001).

Untuk membentuk struktur gel yang baik dan mudah dihisap pada jelly drink dapat ditambakan karagenan. Karagenan dapat membentuk struktur gel yang cenderung elastis, kenyal namun tidak mudah pecah (Mardiana, 2007).
Berdasarkan penelitian sebelumnya penambahan karagenan $0,8 \%$ pada jelly yoghurt srikaya menghasilkan total bakteri asam laktat tertinggi sebesar $8,12 \times 10^{8}$ $\mathrm{cfu} / \mathrm{ml}$ (Harjantini, 2015). Probiotik merupakan suplemen makanan berupa mikrobia hidup yang memberikan efek positif manusia atau hewan dengan memperbaiki keseimbangan mikroflora usus (Surono, 2004). Prebiotik adalah suatu ingredient pangan yang tak tercerna yang mempunyai efek menguntungkan bagi orang yang mengkonsumsinya. Susu kedelai merupakan sumber prebiotik alami karena mengandung karbohidrat jenis galacto-oligosaccharides (GOS) yang tidak dapat dicerna oleh enzim dalam tubuh manusia tetapi dapat dicerna oleh BAL dengan menggunakan enzim $\alpha$ galaktosidase (Martos, 2006). Menurut Wichienchot et al., (2010), buah naga merah mengandungan karbohidrat yang terdiri dari glukosa, fruktosa, dan 
oligosakarida. Oligasakaria inilah yang berperan sebagai prebiotik di dalam tubuh. Kandungan oligosakarida di dalam buah naga merah adalah $89,6 \mathrm{~g} / \mathrm{kg}$ yang terdiri dari raffinosa, stakiosa dan fruktooligosakarida.

Pertumbuhan bakteri asam laktat juga dipengaruhi lama fermentasi. Lama fermentasi akan menentukan kemampuan bakteri asam laktat (BAL) memecah nutrisi menjadi asam laktat pada medium secara optimal.

Menurut penelitian Winarti (2013) menyatakan bahwa bakteri Lactobacillus casei FNCC-90 dan Bifidobacterium breve BRL-131 memiliki aktivitas prebiotik tertinggi karena dapat menggunakan prebiotik (inulin) sebagai sumber energi sampai dengan inkubasi 72 jam dibandingkan dengan Bifidobacterium longum ATCC-15707, Lactobacillus acidophilus $\quad$ FNCC-0051 dan Bifidobacterium bifidum BRL-130.

Oleh karena itu dilakukan penelitian pembuatan minuman kesehatan dalam bentuk jelly drink sinbiotik dari susu kedelai yang kaya senyawa prebiotik dengan pewarna alami ekstrak buah naga merah menggunakan bakteri probiotik Lactobasilus casei FNCC-90 dan Bifidobacterium breve BRL-131 dengan faktor perlakuan penambahan karagenan dan lama fermentasi sehingga dapat menghasilkan jelly drink sinbiotik susu kedelai yang berkualitas, aman dan bermanfaat untuk meningkatkan kesehatan.

\section{METODE PENELITIAN}

\section{Bahan}

Bahan yang digunakan dalam penelitian ini adalah kacang kedelai dan buah naga merah yang diperoleh dari pasar tradisional di Sidoarjo, gula, karagenan (kappa), MRS agar, soda kue $\left(\mathrm{NaHCO}_{3}\right)$, aquades, alkohol 70\%, $\mathrm{NaOH}, \mathrm{HCl}$, $\mathrm{H}_{2} \mathrm{SO}_{4}$, phenopthaline, kultur bakteri
Lactobacillus casei FNCC-90 dan Bifidobacterium breve BRL-131 yang diperoleh dari Pusat Pangan dan Gizi, Universitas Gadjah Mada, Yogyakarta.

\section{Alat}

Alat yang digunakan dalam penelitian ini menggunakan timbangan, lemari pendingin, autoclaf, inkubator, blender, bunsen, pipet, erlenmeyer, pengaduk, gelas piala, kapas, cawan petri, mikropipet, serta alat-alat yang digunakan untuk analisa yaitu $\mathrm{pH}$-meter, termometer, spektrofotometer, tensile strength tipe ZP$200 \mathrm{~N}$ dan colony counter.

\section{Metode}

Penelitian ini dilakukan dengan menggunakan Rancangan Acak Lengkap (RAL) pola faktorial dengan dua faktor dan 2 kali ulangan. Faktor I : Konsentrasi karagenan $(0,4 \%, 0,6 \%$ dan $0,8 \%)$; Faktor II : Lama fermentasi (18 jam, 20 jam, 22 jam dan 24 jam). Data yang diperoleh dianalisa dengan menggunakan analisa ragam. Untuk mengetahui adanya perbedaan diantara perlakuan digunakan Uji Berjarak Duncan (DMRT).

\section{HASIL DAN PEMBAHASAN}

\section{Hasil Analisa Bahan Baku}

Berdasarkan hasil analisa ekstrak buah naga merah dan susu kedelai terhadap beberapa komponen yaitu total gula, protein terlarut, dan total antosianin dapat dilihat pada Tabel 1.

Tabel 1. Hasil analisa bahan baku

\begin{tabular}{lcc}
\hline Analisa & $\begin{array}{c}\text { Susu } \\
\text { kedelai }\end{array}$ & $\begin{array}{c}\text { Buah naga } \\
\text { merah }\end{array}$ \\
\hline Total Gula & - & $1,755 \pm 0,06$ \\
Total & - & $3,84 \pm 0,04$ \\
Antosianin & & - \\
Protein & $5,63 \pm 0,14$ & - \\
Terlarut & & \\
\hline
\end{tabular}

Berdasarkan penelitian Islam et al., (2012) total gula buah naga merah yaitu sebesar $8 \%$. Analisa total gula bertujuan untuk mengetahui total gula pada ekstrak 
buah naga merah, sehingga dapat diketahui substrat yang digunakan oleh bakteri asam laktat selama pertumbuhannya.

Menurut Wu et al., (2005) buah naga merah mengandung antosianin berkisar 8,8 $\mathrm{mg} / 100$ gr buah naga. Analisa total antosianin dilakukan untuk mengetahui total antosianin awal pada ekstrak buah naga merah, sehingga dapat diketahui seberapa banyak penurunan total antosianin selama fermentasi.

Menurut Suprapti (2005), kadar protein terlarut susu kedelai sebesar 3\%$5 \%$ sedangkan kandungan protein terlarut maksimal dalam susu kedelai adalah $7 \%$. Analisa protein terlarut dilakukan untuk mengetahui total protein terlarut pada susu kedelai, dimana protein merupakan substrat yang dapat digunakan oleh bakteri asam laktat dalam pertumbuhannya. Perbedaan hasil analisa dengan literatur disebabkan karena dipengaruhi oleh beberapa faktor antara lain pengaruh pengenceran, perbedaan umur panen, varietas, kondisi lingkungan tempat tumbuh (Hardiyanti, 2011).

\section{Hasil Analisa Jelly Drink Sinbiotik 1. Total Bakteri Asam Laktat}

Berdasarkan hasil analisis ragam menunjukkan bahwa tidak terdapat interaksi yang nyata $(\mathrm{p} \geq 0,05)$ antara perlakuan konsentrasi karagenan dan lama fermentasi terhadap total BAL jelly drink sinbiotik. Pada perlakuan penambahan konsentrasi karagenan dan lama fermentasi terjadi perbedaan yang nyata. Nilai ratarata total BAL jelly drink sinbiotik dengan perlakuan penambahan karagenan dan lama fermentasi dapat dilihat pada Tabel 2 dan Tabel 3.
Tabel 2. Nilai rata-rata total BAL padaperlakuan penambahan karagenan.

\begin{tabular}{ccc}
\hline $\begin{array}{c}\text { Karagenan } \\
(\%)\end{array}$ & $\begin{array}{c}\text { Rerata } \\
\text { Total } \\
\text { BAL }(\log \\
\text { cfu/ml })\end{array}$ & Notasi \\
\hline 0,4 & 11,03 & $\mathrm{~b}$ \\
0,6 & 10,96 & $\mathrm{ab}$ \\
0,8 & 10,92 & $\mathrm{a}$ \\
\hline $\begin{array}{c}\text { Keterangan : Nilai rata-rata yang disertai dengan } \\
\text { huruf yang sama berarti tidak berbeda } \\
\text { nyata pada } \mathrm{p} \geq 0,05\end{array}$
\end{tabular}

Tabel 2. menunjukkan bahwa semakin banyak penambahan karagenan terjadi penurunan total bakteri asam laktat pada jelly drink sinbiotik. Hal ini disebabkan karagenan mampu mengikat air bebas pada produk sehingga menurunkan aktivitas air yang dibutuhkan oleh Lactobacillus casei FNCC-90 dan Bifidobacterium breve BRL-131 dan pertumbuhannya terhambat karena ketersediaan air bebes berkurang. Hal ini sesuai dengan pedapat Nuraini dan Nurdin (2007) menyatakan bahwa konsentrasi polisakarida yang terlalu tinggi akan membuat konsentrasi medium semakin kental sehingga tidak cocok bagi pertumbuhan mikroorganisme.

Tabel 3. Nilai rata-rata total BAL pada perlakuan lama fermentasi

\begin{tabular}{ccc}
\hline $\begin{array}{c}\text { Lama } \\
\text { Fermentasi }\end{array}$ & $\begin{array}{c}\text { Rerata Total } \\
\text { BAL }(\log \\
\text { cfu/ml) }\end{array}$ & Notasi \\
\hline 18 jam & 10,80 & a \\
20 jam & 10,89 & a \\
22 jam & 11,05 & b \\
24 jam & 11,15 & b \\
\hline
\end{tabular}

Keterangan : Nilai rata-rata yang disertai dengan huruf yang sama berarti tidak berbeda nyata pada $\mathrm{p} \geq 0,05$

Tabel 3 menunjukkan bahwa semakin lama fermentasi total bakteri asam laktat semakin meningkat, karena bakteri asam laktat mempunyai waktu yang lebih lama memfermentasi atau menghidrolisis gula menjadi komponen yang lebih sederhana menjadi asam laktat, $\mathrm{CO}_{2}, \mathrm{H}_{2} \mathrm{O}$ dan energi, 
selanjutnya energi akan digunakan untuk sintesis sehingga jumlah sel menjadi meningkat. Menurut Prasyaharasti dkk. (2014) BAL dalam media akan memfermentasi atau menghidrolisis gula menjadi komponen yang lebih sederhana menjadi asam laktat, asam organik, $\mathrm{CO}_{2}$, $\mathrm{H}_{2} \mathrm{O}$ dan energi sehingga terjadi peningkatan total bakteri asam laktat.

\section{Total Asam}

Berdasarkan hasil analisis ragam menunjukkan bahwa tidak terdapat interaksi yang nyata $(p \geq 0,05)$ antara perlakuan penambahan konsentasi karagenan dan lama fermentasi terhadap total asam jelly drink sinbiotik. Pada perlakuan penambahan konsentrasi karagenan dan lama fermentasi terjadi perbedaan yang nyata. Nilai rata-rata total asam jelly drink pada perlakuan penambahan konsentrasi karagenan dapat dilihat pada Tabel 4 dan Tabel 5.

Tabel 4. Nilai rata-rata total asam pada perlakuan penambahan konsentrasi karagenan

\begin{tabular}{ccc}
\hline $\begin{array}{c}\text { Karagenan } \\
(\%)\end{array}$ & $\begin{array}{c}\text { Rerata total } \\
\text { asam }(\%)\end{array}$ & Notasi \\
\hline 0,4 & 1,027 & $\mathrm{~b}$ \\
0,6 & 0,960 & $\mathrm{ab}$ \\
0,8 & 0,892 & $\mathrm{a}$ \\
\hline
\end{tabular}

Keterangan : Nilai rata-rata yang disertai dengan huruf yang sama berarti tidak berbeda nyata pada $\mathrm{p} \geq 0,05$

Pada Tabel 4, menunjukkan bahwa semakin banyak konsentrasi karagenan yang ditambahkan menyebabkan penurunan total asam pada jelly drink sinbiotik. Hal ini terjadi karena hasil metabolisme sel semakin menurun dengan semakin meningkatnya konsentrasi karagenan yang ditambahkan, sebab karagenan merupakan bahan penstabil yang bersifat hidrofilik yang dapat mengikat air pada bahan pangan yang mengakibatkan bakteri asam laktat kekurangan air, nutrisi dan energi untuk menghidrolisis gula menjadi asam laktat. Menurut penelitian Schornburn (2002) menyatakan bahwa adanya bahan penstabil maupun pengental menghambat produksi asam oleh bakteri asam laktat, yang diakibatkan karena aktivitas bakteri asam laktat yang rendah.

Tabel 5. Nilai rata-rata total asam pada perlakuan penambhan karagenan

\begin{tabular}{ccc}
\hline $\begin{array}{c}\text { Lama } \\
\text { fermentasi }\end{array}$ & $\begin{array}{c}\text { Rerata total } \\
\text { asam }(\%)\end{array}$ & Notasi \\
\hline 18 jam & 0,79 & $\mathrm{a}$ \\
20 jam & 0,95 & $\mathrm{~b}$ \\
22 jam & 1,03 & $\mathrm{~b}$ \\
24 jam & 1,07 & $\mathrm{~b}$ \\
\hline
\end{tabular}

Keterangan : Nilai rata-rata yang disertai dengan huruf yang sama berarti tidak berbeda nyata pada $\mathrm{p} \geq 0,05$

Tabel 5 menunjukkan bahwa total asam mengalami peningkatan seiring dengan semakin lama fermentasi pada jelly drink sinbiotik susu kedelai. Selama fermentasi bakteri asam laktat melakukan proses metabolisme yang menghasilkan asam laktat yang disebut sebagai total asam. Akibatnya nilai total asam yang dihasilkan semakin tinggi. Menurut Kusumaningrum (2011), menyatakan bahwa pemecahan gula dalam sel bakteri probiotik akan menghasilkan energi untuk aktivitas bakteri probiotik sehingga dihasilkan asam laktat. Asam laktat kemudian tersekresikan keluar sel dan akan terakumulasi dalam cairan fermentasi sehingga menyebabkan $\mathrm{pH}$ minuman fermentasi turun dan terjadi peningkatan keasaman.

\section{3. $\mathbf{p H}$}

Berdasarkan hasil analisis ragam menunjukkan bahwa terdapat interaksi yang nyata $(\mathrm{p} \leq 0,05)$ antara perlakuan penambahan karagenan dan lama fermentasi terhadap $\mathrm{pH}$ jelly drink sinbiotik dan masing-masing perlakuan berbeda nyata. 
Hubungan antara konsentrasi karagenan dan lama fermentasi terhadap $\mathrm{pH}$ jelly drink dapat dilihat pada Gambar 1.

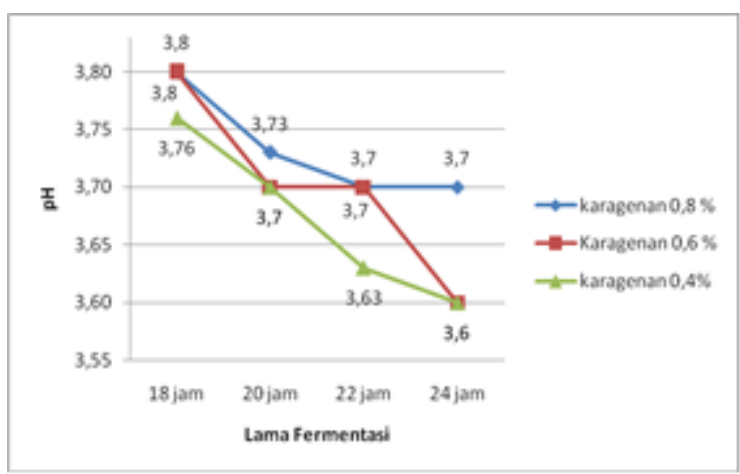

Gambar 1. Hubungan antara konsentrasi karagenan dan lama fermentasi terhadap $\mathrm{pH}$ jelly drink sinbiotik susu kedelai dan ekstrak buah naga merah.

Pada gambar 1 Menunjukkan bahwa semakin rendah konsentrasi karagenan dan semakin lama fermentasi terjadi penurunan $\mathrm{pH}$. Hasil penelitian ini sebanding dengan total asam dimana semakin rendah konsentrasi karagenan dan semakin lama fermentasi total asam meningkan. Penurunan $\mathrm{pH}$ disebabkan oleh asam laktat yang dihasilkan oleh Lactobacillus casei FNCC-90 dan Bifidobacterium breve BRL-131 selama fermentasi, kedua bakteri tersebut merombak gula menjadi asam laktat dan asam-asam organik lain yang dapat menurunkan $\mathrm{pH}$. Menurut Fardiaz (1992), glukosa dirombak oleh bakteri asam laktat menjadi asam piruvat, asam laktat, asam asetat, etatol, dan $\mathrm{CO}_{2}$ yang selanjutnya terjadi menaikkan total asam dan menurunkan pH. Menurut Charalampopoulus et al., (2000) menyatakan bahwa akumulasi asam laktat yang dihasilkan dari metabolisme bakteri asam laktat dapat menurunkan $\mathrm{pH}$ medium.

\section{Total Gula}

Berdasarkan hasil analisis ragam menunjukkan bahwa terdapat interaksi yang nyata $(\mathrm{p} \leq 0,05)$ antara perlakuan konsentrasi karagenan dan lama fermentasi terhadap total gula jelly drink sinbiotik susu kedelai dan masing-masing perlakuan berbeda nyata. Berikut grafik hubungan antara konsentrasi karagena dan lama fermentasi terhadap total gula jelly drink sinbiotik susu kedelai dapat dilihat pada Gambar 2.

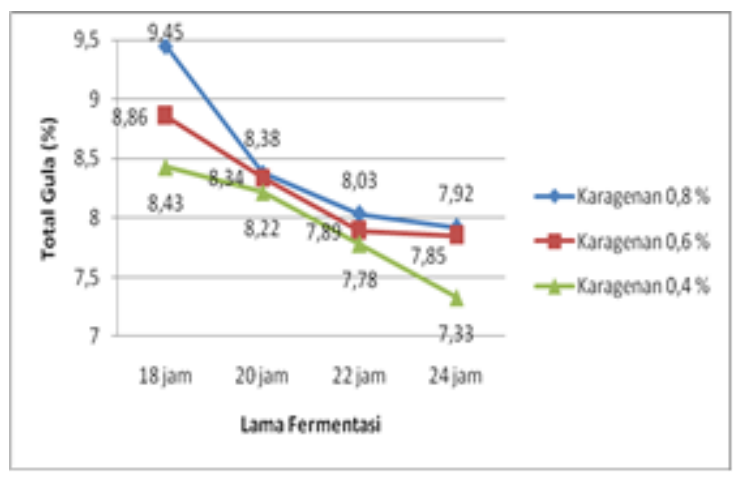

Gambar 2. Hubungan antara konsentasi karagenan dan lama fermentasi terhadap jelly drink sinbiotik susu kedelai dan ekstrak buah naga merah

Gambar 2 Menunjukkan bahwa semakin rendah konsentrasi karagenan dan semakin lama fermentasi terjadi penurunan total gula. Hal ini disebabkan semakin rendah penambahan karagenan dan semakin lama fermentasi terjadi peningkatan total BAL maka total gula terjadi menurun, yang disebabkan oleh bakteri Lactobacillus casei FNCC-90 dan Bifidobacterium breve BRL-131 menghidrolisis gula menjadi asam laktat yang selanjutnya digunakan sebagai metabolit. Menurut Salminen et al., (2004) semakin banyak sel bakteri asam laktat yang terbentuk, maka sumber gula akan semakin banyak digunakan untuk metabolisme sel. Namun, selama proses fermentasi bakteri asam laktat mempunyai batasan optimal untuk dapat menggunakan gula sebagai sumber energi dan karbon sehingga tidak semua gula yang ditambahkan diubah menjadi asam laktat. Gula yang terdapat pada kedelai seperti sukrosa, glukosa, rafinosa maupun stakiosa akan dihidrolisis menjadi senyawasenyawa yang lebih sederhana yang kemudian digunakan bakteri asam laktat sebagai nutrisi pertumbuhannya. LeBlanc 
et al., (2004) menyatakan bahwa enzim $\beta$ galaktosidase akan menghidrolisis sukrosa menjadi glukosa dan fruktosa, sedangkan rafinosa dan stakiosa akan dihidrolisis menjadi glukosa, fruktosa dan galaktosa.

\section{Protein Terlarut}

Berdasarkan hasil analisis ragam menunjukkan bahwa tidak terdapat interaksi yang nyata $(\mathrm{p} \geq 0,05)$ antara perlakuan penambahan konsentrasi karagenan dan lama fermentasi terhadap protein terlarut jelly drink sinbiotik. Pada perlakuan penambahan konsentrasi karagenan dan lama fermentasi terjadi perbedaan yang nyata. Nilai rata-rata protein terlarut jelly drink pada perlakuan penambahan konsentrasi karagenan dapat dilihat pada Tabel 6 dan 7 .

Tabel 6. Nilai rata-rata protein terlarut pada perlakuan penambahan konsentrasi karagenan

\begin{tabular}{ccc}
\hline $\begin{array}{c}\text { Karagenan } \\
(\%)\end{array}$ & $\begin{array}{c}\text { Rerata Protein } \\
\text { Terlarut }(\%)\end{array}$ & Notasi \\
\hline 0,4 & 2,381 & $\mathrm{c}$ \\
0,6 & 1,905 & $\mathrm{~b}$ \\
0,8 & 1,640 & $\mathrm{a}$ \\
\hline
\end{tabular}

Keterangan : Nilai rata-rata yang disertai dengan huruf yang sama berarti tidak berbeda nyata pada $\mathrm{p} \geq 0,05$

Tabel 6. menunjukkan bahwa semakin tinggi konsentrasi karagenan kandungan protein terlarut pada jelly drink sinbiotik semakin rendah. Hal ini terjadi karena kemampuan bakteri untuk memecah protein menjadi asam-asam amino dan peptida yang lebih sederhana lebih sedikit dengan semakin banyak penambahan karagenan, sebab total BAL (Tabel 4.) terjadi penurunan dengan semakin banyak penambahan karagenan yang mengakibatkan terjadi penurunan aktivitas bakteri, sehingga aktivitas proteolitik bakteri juga menurun karena proses pemecahan protein menjadi peptida oleh bakteri asam laktat terhambat dengan semakin tinggi penambahan karagenan. Menurut penelitian Thomas and Mills dalam Hassan and Amjad (2010), menyatakan bahwa kadar protein terlarut berhubungan dengan aktivitas proteolitik bakteri asam laktat, yang mengubah protein menjadi asam amino dan peptida, sehingga akan meningkatkan kadar protein terlarut.

Tabel 7. Nilai rata-rata protein terlarut pada perlakuan lama fermentasi

\begin{tabular}{ccc}
\hline $\begin{array}{c}\text { Lama } \\
\text { fermentasi }\end{array}$ & $\begin{array}{c}\text { Rerata protein } \\
\text { terlarut }(\%)\end{array}$ & Notasi \\
\hline 18 jam & 1,715 & $\mathrm{a}$ \\
20 jam & 1,858 & $\mathrm{a}$ \\
22 jam & 2,083 & $\mathrm{ab}$ \\
24 jam & 2,243 & $\mathrm{~b}$ \\
\hline
\end{tabular}

Keterangan : Nilai rata-rata yang disertai dengan huruf yang sama berarti tidak berbeda nyata pada $\mathrm{p} \geq 0,05$

Tabel 7. Menunjukkan bahwa semakin lama proses fermentasi, protein telarut jelly drink sinbiotik semakin meningkat. Hal ini disebabkan semakin lama fermentasi total bakteri asam laktat menghasilkan enzim protease dan peptidase ekstraseluler untuk memecah protein menjadi peptida yang lebih sederhana, sehingga mengakibatkan jumlah protein yang larut air lebih banyak maka terjadi peningkatan protein terlarut dengan semakin lama waktu fermentasi. Menurut Menurut Onwelune dan Nwabugwu (2009); Amadou dkk (2010), peningkatan kadar protein terlarut dapat dikarenakan selama proses fermentasi, mikroba menghidrolisis protein kompleks menjadi asam amino bebas atau peptida yang lebih sederhana dengan adanya aktivitas enzim proteolitik. Menurut Surono (2004) hidrolisis protein terjadi secara bertahap, yaitu tahap pertama menggunakan enzim proteinase menghasilkan polipeptida dan tahap kedua dilanjutkan oleh aktivitas peptidase menghasilkan asam amino.

\section{Total Antosianin}

Berdasarkan hasil analisis ragam menunjukkan bahwa tidak terdapat 
interaksi yang nyata $(\mathrm{p} \geq 0,05)$ antara perlakuan penambahan konsentrasi karagenan dan lama fermentasi terhadap total antosianin jelly drink sinbiotik. Pada perlakuan penambahan konsentrasi karagenan dan lama fermentasi terjadi perbedaan yang nyata. Nilai rata-rata total antosianin jelly drink pada perlakuan penambahan konsentrasi karagenan dapat dilihat pada Tabel 8 dan 9.

Tabel 8. menunjukkan bahwa semakin tinggi konsentrasi karagenan total antosianin jelly drink sinbiotik semakin menurun. Hal ini disebabkan semakin tinggi karagenan maka total asam yang terbentuk semakin turun (Tabel 4.), $\mathrm{pH}$ meningkat, dengan semakin tinggi $\mathrm{pH}$ maka total antosianin turun. Sifat antosianin sangat dipengaruhi oleh perubahan $\mathrm{pH}$. Pada $\mathrm{pH}$ rendah pigmen antosianin dalam kondisi paling stabil. Hal ini sesuai pendapat Winarno (1994), pada $\mathrm{pH}$ rendah (asam) pigmen antosianin berwarna merah dan pada $\mathrm{pH}$ tinggi berubah menjadi violet dan kemudian menjadi biru. Menurut penelitian Brat et al., (2008) pada kondisi sangat asam antosianin berada dalam kondisi paling stabil dan intensitas warna paling tinggi.

Tabel 8. Nilai rata-rata total antosianin pada perlakuan penambahan konsentrasi karagenan

\begin{tabular}{ccc}
\hline $\begin{array}{c}\text { Karagenan } \\
(\%)\end{array}$ & $\begin{array}{c}\text { Rerata Total } \\
\text { Antosianin }(\%)\end{array}$ & Notasi \\
\hline 0,4 & 0,82 & $\mathrm{~b}$ \\
0,6 & 0,75 & $\mathrm{~b}$ \\
0,8 & 0,55 & $\mathrm{a}$ \\
\hline
\end{tabular}

Keterangan : Nilai rata-rata yang disertai dengan huruf yang sama berarti tidak berbeda nyata pada $\mathrm{p} \geq 0,05$

Tabel 9. Nilai rata-rata total antosianin pada perlakuan lama fermentasi.

\begin{tabular}{ccc}
\hline $\begin{array}{c}\text { Lama } \\
\text { fermentasi }\end{array}$ & $\begin{array}{c}\text { Rerata Total } \\
\text { Antosianin }(\%)\end{array}$ & Notasi \\
\hline 18 jam & 0,60 & $\mathrm{a}$ \\
20 jam & 0,69 & $\mathrm{~b}$ \\
22 jam & 0,73 & $\mathrm{bc}$ \\
24 jam & 0,81 & $\mathrm{c}$ \\
\hline
\end{tabular}

Keterangan : Nilai rata-rata yang disertai dengan huruf yang sama berarti tidak berbeda nyata pada $\mathrm{p} \geq 0,05$

Tabel 9. menunjukkan bahwa selama proses fermentasi terjadi kenaikan total antosianin jelly drink sinbiotik susu kedelai. Selama fermentasi BAL menghasilkan enzim $\alpha$-galaktosidase yang dibutuhkan untuk menghidrolisis gula-gula yang terdapat pada susu kedelai. Hasil metabolisme gula oleh BAL berupa asamasam organik terutama asam laktat, seiring dengan kenaikan total asam selama fermentasi maka terjadi penurunan $\mathrm{pH}$. Pada $\mathrm{pH}$ asam antosianin berada dalam kondisi paling stabil dan intensitas warna paling tinggi. Menurut pendapat Francis (1982), yang menyatakkan bahwa semakin rendah nilai $\mathrm{pH}$ maka warna konsentrat semakin merah dan stabil. Menurut Fennema (1996), pada kondisi asam akan menyebankan semakin banyak pigmen antosianin berada dalam bentuk kation flavilium yang berwarna.

\section{Kekuatan Gel}

Berdasarkan hasil analisis ragam menunjukkan bahwa tidak terdapat interaksi yang nyata $(p \geq 0,05)$ antara perlakuan penambahan konsentrasi karagenan dan lama fermentasi terhadap kekuatan gel jelly drink sinbiotik. Pada perlakuan penambahan konsentrasi karagenan dan lama fermentasi terjadi perbedaan yang nyata. Nilai rata-rata kekuatan gel jelly drink pada perlakuan penambahan konsentrasi karagenan dapat dilihat pada Tabel 10 dan 11.

Tabel 10. Nilai rata-rata kekuatan gel pada perlakuan penambahan konsentrasi karagenan

\begin{tabular}{ccc}
\hline $\begin{array}{c}\text { Karagenan } \\
(\%)\end{array}$ & $\begin{array}{c}\text { Rerata kekuatan } \\
\text { gel }(\%)\end{array}$ & Notasi \\
\hline 0,4 & 1,57 & $\mathrm{a}$ \\
0,6 & 3,12 & $\mathrm{~b}$ \\
0,8 & 3,56 & $\mathrm{c}$ \\
\hline Keterangan : Nilai rata-rata yang disertai dengan \\
huruf yang sama berarti & tidak berbeda \\
nyata pada $\mathrm{p} \geq 0,05$ &
\end{tabular}


Tabel 10 menunjukkan bahwa semakin banyak penambahan karagenan kekuatan gel semakin tinggi, hal ini terjadi karena karagenan mampu membentuk gel. Proses pembentukan gel terjadi karena adanya ikatan antar rantai polimer karagenan dalam larutan berbentuk acak sehingga membentuk struktur tiga dimensi. Selain itu, peningkatan kekuatan gel juga dipengaruhi oleh pengikatan protein oleh karagenan, sebab karagenan yang bermuatan negatif bereaksi dengan muatan prositif dari protein maka membentuk ikatan protein karagenat. Hal ini sesuai dengan Winarno (1996), interaksi protein dengan karagenan mampu menghasilkan peningkatan viskositas, sebab karagenan yang bermuatan negatif bereaksi dengan muatan positif dari protein sehingga terbentuk ikatan protein karagenat. Menurut Penelitian Luthana (2011) menyatakan bahwa kemampuan pembentukan gel pada karagenan terjadi pada saat larutan dipanaskan dan dibiarkan menjadi dingin karena mengandung gugus 3,6-anhidrogalaktosa.

Tabel 11. Nilai rata-rata kekuatan gel pada perlakuan lama fermentasi.

\begin{tabular}{ccc}
\hline $\begin{array}{c}\text { Lama } \\
\text { fermentasi }\end{array}$ & $\begin{array}{c}\text { Rerata } \\
\text { Kekuatan gel } \\
(\mathrm{N})\end{array}$ & Notasi \\
\hline 18 jam & 3,05 & $\mathrm{c}$ \\
20 jam & 2,92 & $\mathrm{c}$ \\
22 jam & 2,60 & $\mathrm{~b}$ \\
24 jam & 2,43 & $\mathrm{a}$ \\
\hline
\end{tabular}

Keterangan : Nilai rata-rata yang disertai dengan huruf yang sama berarti tidak berbeda nyata pada $\mathrm{p} \geq 0,05$

Tabel 11 menunjukkan bahwa selama proses fermentasi terjadi penurunan kekuatan gel jelly drink sinbiotik susu kedelai. Semakin lama fermentasi terjadi penurunan kekuatan gel yang disebabkab oleh bakteri asam laktat menghidrolisis gula dan protein menjadi komponen yang lebih sederhana yang mengakibatkan terjadi penurunan $\mathrm{pH}$ yang disebabkan oleh ion $\mathrm{H}^{+}$yang berasal dari perombakan senyawa asam hasil metabolisme BAL yang kemudian dapat menghidrolisis ikatan glikosidik molekul karagenan yang mengakibatkan terjadi penurunan kekuatan gel. Menurut Angka dan Suhartono (2000), pembentuk gel dan viskositas larutan karaginan akan menurun dengan menurunnya $\mathrm{pH}$, karena ion $\mathrm{H}^{+}$membantu proses hidrolisis ikatan glikosidik pada molekul karagenan.

\section{KESIMPULAN}

Hasil penelitian menunjukan bahwa dengan penambahan konsentrasi karagenan 0,8\% dan lama fermentasi 24 jam menghasilkan jelly drink sinbiotik

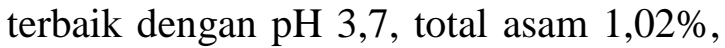
total BAL $11,13 \log \mathrm{cfu} / \mathrm{ml}$, total gula $7,92 \%$, protein terlarut $1,89 \%$, total antosianin $0,645 \%$ dan kekuatan gel 3,27 $\mathrm{N}$.

\section{DAFTAR PUSTAKA}

Ahmed Z, Y Wang, Q Cheng, M Imran. 2010. Lactobacillus acidophillus bacteriocin, from production to their application: an overview. African Journal of Biotechnology 9(20):2843-2850.

Akmar Atsmanul. 2006. Aktivitas Protease dan Kandungan Asam Laktat pada Yoghurt yang Dimodifikasi Bifidobacterium spp. dan diinokulasi Pseudomonas fluorescens (Skripsi). Bogor: Fakultas Matematikan dan Ilmu Pengetahuan Alam, IPB.

Allen SJ, EG Martinez, GV Gregorio, LF Dans. 2011. Probiotics for treating acute infectious diarrhoea. John Wiley \& Sons Ltd. UK.

AOAC. 1995. Official Methods of Analysis of the Association of Official Analytical Chemists. Association of Official Analytical Chemists. Washington, D.C

Apriyantono, A., D. Fardiaz., N. L. Puspitasari., Sedarnawati dan S. Budiyanto. 1989. Analisa Pangan. IPB Press. Bogor. 
Arixs. 2006. Mengenal Olahan Bahan Pangan Nonberas Bali, Denpasar, Bandung. Di dalam : Hidayah, T. Pratjojo, W. Widiarti, N. 2014. Uji Stabilitas Pigmen dan Antioksidan Ekstrak Zat Warna Alami Kulit Buah Naga. Indonesian Journal Of Chemical Science 3 (2).

Astawan, Made. 2004. Tetap Sehat dengan Produk Makanan Olahan. Tiga Serangkai. Solo.

Ballongue J. 1993. Bifidobacteria and Prebiotic Action. Di dalam: Salminen S, Wright AV, editor. Lactid Acid Bacteria. New York: Marcel Dekker.

Bordignon JR, Nakahara K, Yoshihashi T, Nikkuni S. 2004. Hydrolysis of isoflavone and consumption of oligosacharides during lactic acid fermentation of soybean milk. JARQ 38 (4) 259-265.

Buchanan RE, Gibbons. 1975. Bergey's Manual of Determinative Bacteriology. 8thedition. Baltimore, USA : Woverly.

Chaitow L, N Trenev. 1990. Probiotics. London: Thorson.

Charalampopoulus, D. R., Wang S.,S. Pandiella and C. Webb. 2002. Aplication Of Cereals And Cereal Component In Functional Food : a Review international journal of microbiology.79:131-141

Collins, M.D. and G.R. Gibson. 1999. Probiotocs, Prebiotics and synbiotics: Approaches for modulating the Microbial ecology of the gut.Amj. Clin Nutr. 69;15251575 .

Ezekiel,O.O., Ogugua, C.,Hans, A., Blaschek, P. Dan Ezeji T.C. 2010. Protein enrichment of cassava Peel by Submerged Fermentation with Trichoderma Viride (ATCC 36316). Africa journal of Biotecnology 9: 187-194
FAO/WHO. 2001. Joint FAO/WHO Expert Consultation on Evaluation of Health and Nutritional Properties of Probiotics in Food Including Powder Milk with Live Lactic Acid Bacteria. Amerian Córdoba Park Hotel, Córdoba, Argentina.

Fardiaz, S. 1992. Mikrobiologi Pengolahan Pangan Lanjut. Dep. Pendidikan dan Kebudayaan Direktor Jendral Pendidikan Tinggi Pusat Antar Universitas Pangan dan Gizi. Bogor. IPB

Fennema, O.R.,1996.Food Chemistry,Thrid Edition.New York: Marcel Dekker Inc.

Fooks, L.J., Fuller, R. and Gibson, G.R. 1999. Prebiotics, Probiotics and Human Gut Microbiology. Probiotica .9:2-7.

Fuller, R. 1989. A Review Probiotic in Man and Animals. Journal of Applied Bacteriology. 66: 365-378.

Gibson, G.R. and R. Fuller. 1991. Functional food. Di dalam : Fithri C N, Kusnadi J, Chrisnasari R. 2008. Viabilitas dan Deteksi Subletal Bakteri Probiotik Pada Susu Kedelai Fermentasi Instan Metode Pengeringan Beku (Kajian Jenis Isolasi dan Konsentrasi Sukrosa Sebagai Krioprotektan). Jurnal Teknologi Pertanian. Vol.9 N0. 1

Glicksman, M. 1983. Food Hydrocolloids. Volume I. CRC Press Boca Raton, Florida. 207 pp.

Gourbeyre, P., Denery, S. dan Bodinier, M. 2010. Probiotics, Prebiotics, and Synbiotics: impact on the gut immune system and allergic reactions. Journal of Leokocyte Biology 89(5): 685-695.

Guarner, F., Aamir G. Khan, James G., Rami E., Alfred G., Alan T., Justus K., Ton L. M., Pedro K., Juan A. de Paula., Richard F., Fergus S., Mary E. S., Hania. 2008. Probiotics and 
Prebiotics. World Gastroenterology Organisation Practice Guideline.

Ha, M.Y.,Kim, S.W.,Lee, Y.W.,Kim, M.Y., and Kim, S.J. 2003. Kinetic analysis of growth and lactic axcid production in $\mathrm{pH}$ control batch cultures of Lactobacillus casei $\mathrm{KH}-1$ using yeast extrack/com steep liquor/glucose medium. Journal biosienceand bloengenering. Vol. 96. P. 134-14

Habibillah, F. 2009. Pengaruh Variasi Konsentrasi dan Perbandingan Starter Bakteri (Lactobacillus acidophilus) dan (Bifidobacterium bifidum) Terhadap Kualitas Yoghurt Susu Kambing (Skripsi). Jurusan Biologi Fakultas Sains dan Teknologi UIN Maliki Malang.

Hadiwiyoto, S. 1994. Teori dan Prosedur pengujian Mutu Susu dan Hasil Olahannya. Liberty. Yogyakarta.

Hanum, T. 2000. Ekstraksi dan Stabilitas Zat Pewarna Alami dari Katul Beras Ketan Hitam (Oryza sativa glutinosa). Buletin Teknologi Pangan, Vol XI, No. 1. 17 - 23.

Harish, K and T. Varghese. 2006. Probiotics in Human - Evidence Based Review. Di dalam: Sawitri, M E. 2011. Kajian Penggunaan Ekstrak Susu Kedelai Terhdapa Kualitas Kefir Susu Kambing. Jurnal Ternak Trapika Vol. 12 No.1 : 15-21.

Hasan, A And I. Amjad. 2010. Nutritional Evaluation Of Yoghurt Prepared By Different Starter Cultur And Their Physiochemical Analysis During Storage. African Journal Of Mikrobiology Research Vol. 4 (1), Pp. 022-026

Helferich W., Dennis C. dan Westhoff. 1980. All about yoghurt. Dalam : Yunus, Y dan Zubaidah, E. 2015. Pengaruh Konsentrasi Sukrosa dan Lama Fermentasi Terhadap Viabilitas L.casei Selama Penyimpanan Beku Velva Pisang
Ambon. Jurnal pangan dan agroindustri Vol.3 No 2 p. 303-312.

Hidayat, T., Pratjojo, W., Widiarti., N. 2014. Uji Stabilitas Pigmen dan Antosianin Ekstrak Zat Warna Alami Kuit Buah Naga. Indonesia Journal of Chemical Science 3 (2) (2014).

Khotimah, K., Kusnadi, J. 2014. Aktivitas Antibakteri Minuman Probiotik Sari Kurma (Phoenix dactilyfera L.) Menggunakan Lactobacillus plantarum dan Lactobacillus casei. Jurnal Pangan dan Agroindustri Vol.2 No.3 p.110-120.

Koswara, S .2009. Teknologi Pembuatan Yoghurt.Tekpan.unimus.ac.id/wpcontent/.../Teknologi-PembuatanYoghurt.pdf.Ebookpangan.com

Koswara, S., 1992. Teknologi Pengolahan Kedelai Menjadikan Makanan Bermutu. Pustaka Sinar Harapan, Jakarta.

Li Chen Wu, Hsiu-Wen Hsu, Yun-Chen Chen, Chih-Chung Chiu,Yu-In Lin and Annie Ho . 2005. Antioxidant And Antiproliferative Activities of Red Pitaya. Department of Applied Chemistry, National Chi-Nan University, Nomor 1University Road, Puli, Nantou, 545 Taiwan

Lomax, A.R., Calder P.C., 2010. Prebiotics, Immune Function, Infection and Inflammation: A Review of the Evidence. Institute of Human Nutrition, School of Medicine, University of Southampton.

Mubin, M.F. dan Zubaidah, E. 2016. Studi Pembuatan Kefir Nira Siwalan (Borassus Flabellifer L.) (Pengaruh Pengenceran Nira Siwalan Dan Metode Inkubasi). Jurnal Pangan dan Agroindustri Vol. 4 No 1 p.291-301. Nakazawa Y, Hasono A. 1992. Function of Fermented Milk. London: Elsevier Applied Science. 
Noer H. 2006. Hidrokoloid dalam Pembuatan Jelly Drink. Food Review. Vol 1 Edisi 2 Maret 2006.

Nuraini, F Dan Nurdin, S.U. 2007. Produksi Minuman Sinbiotik Ekstrak Cincau Hijau Sebagai Minuman Fungsional. Penelitian Dosen Muda. Fakultas Pertanian. Universitas Lampung. Lampung.

Oberman And Libudzisz. 1998. Fermented Milks. Elselver Applied Science. Pub. New York.

Oboh, G. Dan Elusiyan, C.A. 2007. Changes in the nutrient dan anti nutrient content of micro-fungi fermented cassava flour produced from low- and medium-cyanide variety of cassava tubers. African Journal of Food Science 2: 136-142.

Onweluzo, J.C dan Nwabugwu, C.C. 2009. Fermentation of miller (pennisetum americanum) and pigen pea (cajanus cajan) seeds for flour production: effects on composition and selected functional properties. Pakistan Journal Of Nutrition 8: 737-744

Pomeranz Y. 1991. Functional properties of food components (2nd ed), California. Academic Press, Inc.

Prado, F. C., J. L. Parada, A. Pandey, and C. R. Soccol. 2008. Trends in nondairy probiotic beverages. Food Res. Int. 41: 111-123..

Pranayanti, I. A. P Dan Sutrisno, A. 2015. Pembuatan Minuman Probiotik Air Kelapa Muda (Cocos nucifera L.) Dengan Starter Lactobacillus Casei strain Shirota. Jurnal Pangan dan Agroindustri Vol. 3 No 2 P.763-772, April 2015.

Prior, R.L., Cao, G., Martin A., Soffic E., McEwen J., O’Brien C., Lishchner N., Ehlenfeldt M., Kalt W., Kreawer G., Mainland C.M., 1998. Antioxidan Capa-city as Influenced by Total Phenolic and Antochyanin Content, Maturity And Variety of
Vaccanium Spesies, J. Agric. Food Chem. 46 (7): 2686-2693.

Rahayu, E S. 2001 Potensi dan Peranan Prebiotik dan Probiotik Dalam Makanan Sehat. Seminar Prebiotik, Probiotik dan Makanan Sehat. Fakultas Biologi Universitas Atmajaya. Yogyakarta.

Rahman, A. 2005. Pengaruh Penambahan Karagenan Dan Agr Pada Berbagai Konsentrasi Terhadap Sifat Fisik Kimia dan Organoleptik "Jelly Drink" Tomat (Lycopercium Esteluntum Mill). Skripsi FTP Unibraw. Malang.

Roberfroid, M.B. 2000. Prebiotics and probiotics : Are They Functional Food?1-3. The American Journal Of Clinical Nutrition 71. Pp. 1682S1687S.

Sasminto E, Mulyaningsih S, Untari E K,Widyaningrum R. 2006. Aktivitas imunostimulan susu kedelai terhadap immunoglobulin dan proliferasi sel limfosit pada mencit $\mathrm{Babl/c}$ yang di induksi hepatitis A. Majalah Farmasi Indonesia. 17(3):156-161.

Sawitri, M E. 2011. Kajian Penggunaan Ekstrak Susu Kedelai Terhdapa Kualitas Kefir Susu Kambing. Jurnal Ternak Trapika Vol. 12 No.1 : 15-21. Schornburn, R. 2002. The Effects of Various Stabilizers on The Mouthfeel and Other Attributes of Yoghurt. University of Florida.

See D, Mason S, Roshan R, 2002. Increased tumor necrosis factor alpha (TNF-alpha) and Natural killer cell (NK) function using integrative approach in late stage cancers, available.

Setyorini, D .A, M Arifin, Nurwantoro. 2010. Karakteristik sosis Probiotik Daging Sapi menggunakan Lactobacillus casei dan Bifidobacterium sp Pada Lama Penyimpanan Yang Berbeda. 
Seminar Nasional Teknologi Peternakan dan Veteriner.

Shah, N. P. And R. R. Ravula. 2000. Influence Of Water Activity On Fermentation, Organic Acids Production And Viability Of Yoghurt And Probiotic Bacteria. Australian Journal Of Dairy Technology. 5 (3): 127-131

Smith, M.A.L.,K.A. Marley, D. Seigler, K.W. Singletary and B. Meline. 2000. Bioactive propertion of wild bluberry fruit. J. Food Sci. 65 (2):352-356.

Soomro, A. H., Masud, T., and Anwar, K. 2002. Role Of Lactic Acid Bacteria (LAB) In Food Preservation And Human Health-a Review. Pakistan Journal of Nutrition. 1(1):20-24, 2002

Suaidah, H dan Zubaidah, E. 2012. Viabilitas Lactobacilus casei Pada Jelly Drink Probiotik Ubi Jalar Ungu Jepang Selama Penyimpanan (Kajian Konsentrasi Sukrosa dan Karagenan). Skripsi FTP Unibraw. Malang.

Sudarmadji S, Haryono B, Suhardi. 1997. Prosedur Analisa Untuk Bahan Makanan dan Pertanian. Fakultas Teknologi Pertanian Universitas Gadjah Mada. Liberty. Yogyakarta.

Sunaryanto R, Martius E, Marwoto B 2014. Uji Kemampuan Lactobacillus Casei sebagai agensia probiotik. Jurnal Bioteknologi \& Biosains Indonesia Vol 01 Nomer 01.

Takeshi, M. 2003. Health properties of milk fermented with Lactobacillus casei strain Shirota (LcS). Dalam: Farnworth, E. R. (Ed). Handbook of
Fermented Functionl Foods (hal. 145-175). CRC Press LLC, Boca Raton, FL.

Towle, A.G., 1973. Carrageenan. In : R.L Whistler (Ed). Industrial Gum : Polysacharides and Their Derivates. Academic Press. London.

Usmiati, S. Utami, T. 2008. Pengaruh Bakteri Probiotik Terhadap Mutu Sari Kacang Tanah Fermentasi. J.Pascapanen 5(2) 2008: 27-36

Uzzan, M. dan labuza, T., 2004. Critical issues in R and D of soy isoflavoneenriched foods and dietary supplements. Journal of Food Science, 69 (3): CRH77-CRH86

Varnam, H.A. and Sutherland, J.P., 1994. Beverages (Technology, Chemestry and Microbiology). Chapman and Hall, London.

Winarno FG.2008.Kimia Pangan dan Gizi.M-Brio Press, Bogor.

Winarti, S. 2010. Makanan Fungsional. Graha ilmu. Yogyakarta.

Winarti, S. 2013. Karakteristik dan evaluasi sifat prebiotik inulin umbi gembili (Dioscorea esculenta) [Disertasi]. Yogyakarta : Fakultas Teknologi Pertanian. UGM.

Winarti, S.,Harmayani, E. And Nurismanto, R. 2011. Karakteristik dan profil inilun beberapa jenis umbi uwi (Dioscorea spp). AGEITECH, 31 (4) : 378-383.

Winarti, S., E. Harmayani, Y. Marsono dan Y. Pranoto. 2013. Pengaruh Foaming Pada Pengeringan Inulin Umbi Gembili (Dioscorea esculenta) terhadap karakteristik fisiko-kimia dan aktivitas prebiotik. AGRITECH, Vol.33, No.4: 424-432. 